\title{
Opinion and expectation of the community who come to the parks for doing sports (Applications in Gaziantep)
}

\author{
Huseyin OZTURK
}

School of Physical Education and Sport, Gaziantep University, Gaziantep, Turkey (e-mail; ozturkavrasya@hotmail.com).

\begin{abstract}
This study was prepared to determine the opinions and expectations of the community who come to the parks for doing sports. The popoulation consists of the people who come to parks in Gaziantep for doing sports. Including 480 female and 372 male totally 852 people participated to resarch. Survey method (scanning) and the views and expectations survey which was developed by Tatlı was used for the study. A total number of 852 people, 480 women and 372 men, participated in the research. SPSS 18 statistical packaged software used for analysis of the datas obtained. To comment the results percentage, frequency distribution and $X^{2}$ technique were used. The research results indicated that people come to the parks and doing sport for living a healhty lifestyle, they prefer parks because of free charge and they feel healthy and spry after doing sport. High incidence of the participants want to study with a personal trainer, when consulted by gender women are doing sports to ensure weight control, while men want to do bodybuilding. There is not a significant relation between wish to do sport with a personal trainer and occupational group and when examined the relation between educational status and preference to do sports in parks, it is concluded that primary and secondary school graduates prefer parks because their childen can play in the park while they are doing sport, high school graduates prefer parks because gyms have environment and hygiene problems, university graduates and above prefer parks beacuse gym membership fees are high.
\end{abstract}

Keywords: Expectation, leisure, opinion, sport.

\section{INTRODUCTION}

In developing and changing world individulas had to contend with a number of stress sources. One of the major problem in this contention is individuals want to spend their leisure time resting, amusing or obtaining benefits. Concordantlythe need for moving freely again, which is a natural right of the people increased in developing community (31).

Leisure is defined as a period of time that one can get rid of all the obligations and duties of himself /herself and to the others and spent time in activities that are chosen voluntarily for entertainment, recreation or self-improvement $(7,6,16,32)$

Leisure time generally defined as recreation concept. Recreation contribute to indivuduals to get rid of the monotony of life with cultural and sportive activities which are proper to individual personality and one participate voluntarily and enjoy it (24).
Recreation areas have become one of the most important leisure activity areas in developing and changing world and began to find hisself place with different uses especially in the city life (24). Open areas, which are increasingin number and giving opportunity to benefit leisure time almost everywhereand has become one of the areas that participants benefit mostly (9).

For these reasons, preparation environments to allow individuals live happier and peacefully has become the main target of the leisure managers, various institutions and organizations but first of all municipalities. To achieve this target, it is required to create an environment that individulas commune with nature and environment, amuse and rest. In this sense, preparation of the areas where people can spend their times with sport activities considered as a remarkable matter. During the recent years, an increasing number of outdoor sports and leisure parks in Turkey demonstrated the relationship between leisure, entertainment, recreational and 
sport activities effectively and contributed to the creation of activities named as sporting recreation.

Conducted researches indicate that socioeconomic developped societies spend their leisure time with recreational activities and outside the home. Recreation is a fact that which has an increasing importance in community life and expanding fastly (26). Another research result shows that thanks to exercises done in open area, individuals have opportunity to change positively in aspects of psychological relief, refreshment, avoidance from stress and social relationships $(10,18,20-22)$.

Exercisesdone in outdoor sports parks, as well as its psychological benefits also contributes to the individualin terms of prevention of various diseases such as osteoporosis and type-2 diabetes (30). Obtaining the health benefits require regular and programmed physical activities (34).

As a result, economic provide outdoor sportsparks,a number ofenvironmentalandsocial benefits (is free). However, these benefits show up with designing qualified sports parks and increasing the fitness conscious of individuals.

Sport benefits only if it is done in a conscious way. Its negative effects come up when it is done unconsciously and these negative results can cause to irremediable and serious illnesses. Local governments must dwell on their services about this subject sensitively. Sports activities must be carried out under the supervision of specialists who will coordinate the activities and we believe that it will be the most accurate way. It is thought that done study with the coorparation of School of Physical Education and Sports within scientific scope both provide people to do sports in a conscious and efficient way and increase the satisfaction of the people to the municipality. This study aimed to determine views and expectations of people who came to park to do sport. Also to inform the municipalities if there is a deficiency for fixing it.

\section{MATERIAL \& METHOD}

\section{Population and Sample}

The popoulation consist of people, who come to the parks for doing sport. Population is determined with random sample method and total of 852 people, 480 women and 372 menwho comes for doing sport, participated in this reserach.

\section{Data Collection}

Within the scope of data collection,we confered with the people one to one, who come to parks for doing sport in Gaziantep after giving information about this research, a survey were conducted to volunteer candidates who wish to participate in the study.

\section{Data Collection Tools}

The survey method was used to collect the data needed for the research. 6 of the questions in the survey are for determining the demographic informations of people, while 12 of them developped by Tatlı (31) and aimed at determining the opinions and expectations about sport parks.

\section{Analysis of Data}

SPSS 18 statistical packaged software used for analysis of the datas obtained. To comment the results percentage, frequency distribution and $\mathrm{X}^{2}$ technique were used. Data solution age, gender, occupation, education level, marital status, arguments about the effects on the sport in question to engage in sports with a sports park on the monthly net income is compared. $\mathrm{X}^{2}$ method used for this comparison. The significance level between demographic questions and some other questions examined while using this method.

\section{RESULTS}

When Table 1 examined it was concluded that $480(56.3 \%)$ of the participants are women, 372 $(43.7 \%)$ of them are men, $641(75.2 \%)$ of the participants are married and most of the participants are house wifes consist of 292 (34.3\%) women, most of the participants consist of 268 person $(31.5 \%)$ are salaried between 1501-2000 TL and most of them are primary school graduates 275 person $(32.3 \%)$.

When Table 2 examinedand considering intended purposes of the participants about sports fields in the parks, $315(37 \%)$ of the participants chose living a healthy life and $465.4(\%)$ of the participants chose having a clear mind by doing sport.

When Table 3 is examined and considering the reasons for prefering parks for doing sport, free charge is the predominant reason and consist of 261 persons $(30.6 \%)$, environment and hygiene problems of gyms is least effective reasons and consists of 38 persons $(4.5 \%)$. 
Table 1. Personal informations about participants.

\begin{tabular}{|c|c|c|c|}
\hline Variable & Groups & $\mathrm{n}$ & $\%$ \\
\hline \multirow[t]{2}{*}{ Gender } & Woman & 480 & 56.3 \\
\hline & Man & 372 & 43.7 \\
\hline \multirow[t]{2}{*}{ Marital Status } & Married & 641 & 75.2 \\
\hline & Bachelor & 211 & 24.8 \\
\hline \multirow[t]{5}{*}{ Age } & 20 aged and below & 74 & 8.7 \\
\hline & 21-30 aged & 159 & 18.7 \\
\hline & $31-40$ aged & 264 & 31 \\
\hline & 41-50 aged & 275 & 32.3 \\
\hline & 51 aged and above & 80 & 9.4 \\
\hline \multirow[t]{7}{*}{ Occupation } & Housewife & 292 & 34.3 \\
\hline & Unemployed & 54 & 6.3 \\
\hline & Civil Servant & 65 & 7.6 \\
\hline & Worker & 133 & 15.6 \\
\hline & Private Sector Employee & 71 & 28.4 \\
\hline & Retired & 111 & 13 \\
\hline & Student & 48 & 5.6 \\
\hline \multirow[t]{4}{*}{ Monthly Income } & $900-1500$ & 231 & 27.1 \\
\hline & $1501-2000$ & 268 & 31.5 \\
\hline & $2001-2500$ & 184 & 21.6 \\
\hline & $900-1500$ & 231 & 27.1 \\
\hline \multirow{4}{*}{$\begin{array}{l}\text { Educational } \\
\text { Status }\end{array}$} & Primary School & 275 & 32.3 \\
\hline & Secondary School & 218 & 25.6 \\
\hline & High School & 211 & 24.8 \\
\hline & University and above & 148 & 17.4 \\
\hline
\end{tabular}

Table 2. Intented purposes of the participants about sports fields in the parks.

\begin{tabular}{lcc}
\hline & \% & f \\
\hline & & \\
Live a healthy Lifesyle & 315 & 37.0 \\
Ensure the Weight Control & 178 & 20.9 \\
Having a Clear Mind by doing sport & 46 & 5.4 \\
To expand my social circle & 30 & 3.5 \\
Make use of my spare time & 125 & 14.7 \\
To develop my muscles & 71 & 8.3 \\
Being in nature & 87 & 10.2 \\
& & \\
\hline
\end{tabular}

When Table 4 examined, participants mostly prefered the "feeling healthy and spry" option after doing sport and consist of 271 person $(31.8 \%)$ and "feeling peaceful" is the least preferred option consist of 80 person $(9.4 \%)$

When Table 5 examined it was seen that participants preferred to working out under the supervision of sport specialists in the parks at high level and consist of 671 persons $(78.8 \%)$.
When Table 6 examined and considering the relationship between gender and purposes of the participants, women's purposes are respectively ensure the weight control $78.7 \%$, to expand their social circle $73.3 \%$, to live a healthy life $56.5 \%$, while men's purposes of using sports implements in the parks are respectively to develop their muscles $80.3 \%$, having a clear mind by doing sport $65.2 \%$, make use of their spare time $50.4 \%$.

There is not a significant relation between occupational group of participants and preference of working out under the supervision of sport specialists $(\mathrm{p}=0.75)$.

Table 3. The reasons for prefering parks for doing sports.

\begin{tabular}{lcc}
\hline & \% & f \\
\hline & & \\
Because of free charge & 261 & 30.6 \\
For doing sport in fresh air & 154 & 18.1 \\
Gym membership fees are high & 142 & 16.7 \\
It is close to my home & 154 & 18.1 \\
My child can play in the park while I'm & 103 & 12.1 \\
doing sport & & \\
I think that gyms have environment and & 38 & 4.5 \\
hygiene problems & & \\
& & \\
\hline
\end{tabular}

Table 4. Feelings of the participants after doing sport in parks.

$\% \quad f$

$\begin{array}{lcc}\text { Tired and Exhausted } & 128 & 15.0 \\ \text { Happy } & 168 & 19.7 \\ \text { Healthy and Spry } & 271 & 31.8 \\ \text { Feel Pain in my Body } & 115 & 13.5 \\ \text { Peaceful } & 80 & 90.4 \\ \text { Feel Comforted Psychologically } & 90 & 10.6\end{array}$

Table 5. The preference of the participants working out under the supervision of specialists in the parks.

\begin{tabular}{ccc}
\hline & \% & $\mathbf{f}$ \\
\hline & & \\
Yes & 671 & 78.8 \\
No & 181 & 21.2
\end{tabular}

When Table 7 examined and considering the reasons of choosing parks for doing sport and educational status, primary and secondary school graduates (respectively, $46.6 \%, 34.0 \%$ ) prefer parks because their children can play in the park while they are doing sport, high school graduates $(36.8 \%)$ prefer park because the gyms have environment and hygiene problems, university 
graduatesand above (32.4\%) prefer parks beacuse gym membership fees are high.

Table 6. The Relationship between Gender and Purposes of the Participants Doing Sport in Parks.

\begin{tabular}{|c|c|c|c|c|}
\hline & & Women & Men & $\begin{array}{l}\text { Chi- } \\
\text { square }\end{array}$ \\
\hline \multirow[t]{2}{*}{ Live a healthy Lifesyle } & $\mathrm{n}$ & 178 & 137 & \\
\hline & $\%$ & 56.5 & 46.5 & \\
\hline \multirow[t]{2}{*}{ Ensure the Weight Control } & $\mathrm{n}$ & 140 & 37 & $X^{2}=89.30$ \\
\hline & $\%$ & 78.7 & 21.3 & $\mathrm{df}=6$ \\
\hline \multirow{2}{*}{$\begin{array}{l}\text { Having a Clear Mind by } \\
\text { doing sport }\end{array}$} & $\mathrm{n}$ & 16 & 30 & $\mathrm{P}<0.05$ \\
\hline & $\%$ & 34.8 & 65.2 & \\
\hline \multirow[t]{2}{*}{ To expand my social circle } & $\mathrm{n}$ & 22 & 8 & \\
\hline & $\%$ & 73.3 & 26.7 & \\
\hline \multirow[t]{2}{*}{ Make use of my spare time } & $\mathrm{n}$ & 62 & 63 & \\
\hline & $\%$ & 49.6 & 50.4 & \\
\hline \multirow[t]{2}{*}{ To develop my muscles } & $\mathrm{n}$ & 14 & 57 & \\
\hline & $\%$ & 19.7 & 80.3 & \\
\hline \multirow[t]{2}{*}{ Being in nature } & $\mathrm{n}$ & 48 & 39 & \\
\hline & $\%$ & 56.3 & 43.7 & \\
\hline
\end{tabular}

\section{DISCUSSION}

Four houndred-eighty (56.3\%) women and $372(43.7 \%)$ men participated in the research.The results of the study done by Bulgu et al. (8) and named as "Daily Living, Women and Physical Activity" indicated that the creation of new opportunities for women to participate in physical activities in recent years, effects of women's movement, increase in health and physical fitness movements increased the participation of women in physical activities. In the study done by Ay (4) and named as "Advantages and Disadvantages of Using Exercises Areas in the Parks Burdur City
Center Study" women predominate at a rate of $71.6 \%$ when the gender of the participants examined. As a result of the study done by Henderson (15), it was concluded that women have less opportunity to participate inrecreation activities beause they have to look after children and do the houseworks. Alexandris \& Carroll (2) consistsof women of more restrictiveintheir studydid, it was concludedthat there isreasontodo lesssportsthan men.

Mostly married people, 641 persons (75.2\%) appear to be. As a result of the study done by Ağılönü (1) and named as "Recreation Services in Local Governments and Model Determination" (Fethiye Example), the participants consist of married people at the rate of $93.8 \%$, while the study done by. Mengütay et al. (19) made clearthatthePoint-to Leisure Activities Participate Employees in Local Governance Causes and Outcomes from work seems to behigher than 78.6 $\%$ of the proportion ofthe married participants.

It is seen that most of them, 275 persons $(32.3 \%)$, are primary school graduates. Considering the results, it is seen that the study is similar to some other studies and also difference from some other studies. As a result of the study done by Ağılönü (1), it is seen that most of the participants are secondary school graduates at the rate of $61.6 \%$. Özdemir et al. (23) conducted a study on mineworkers, who work at General Directorate of Hard Coal; about determination of recreation routines and itis seen that most of the participants are primary school graduates at the rate of $48.2 \%$.

\begin{tabular}{|c|c|c|c|c|c|c|}
\hline & & $\begin{array}{l}\text { Primary } \\
\text { School }\end{array}$ & $\begin{array}{r}\text { Middle } \\
\text { School }\end{array}$ & $\begin{array}{c}\text { High } \\
\text { School }\end{array}$ & $\begin{array}{c}\text { University } \\
\text { and Up }\end{array}$ & Ki-Kare \\
\hline \multirow[t]{2}{*}{ Because of Free charge } & $\mathrm{n}$ & 105 & 76 & 54 & 26 & \\
\hline & $\%$ & 40.2 & 29.1 & 20.7 & 10 & \\
\hline For doing sport in fresh air & $\mathrm{n}$ & 41 & 32 & 53 & 28 & $X^{2}=92.49$ \\
\hline \multirow[t]{2}{*}{ Gym membership fees are high } & $\mathrm{n}$ & 20 & 30 & 46 & 46 & $\mathrm{P}<0.05$ \\
\hline & $\%$ & 14.1 & 21.1 & 32.4 & 32.4 & \\
\hline \multirow[t]{2}{*}{ It is close to my home } & $\mathrm{n}$ & 47 & 41 & 34 & 32 & \\
\hline & $\%$ & 30.5 & 26.6 & 22.1 & 20.8 & \\
\hline My child can play in the park while I'm & $\mathrm{n}$ & 48 & 35 & 10 & 10 & \\
\hline
\end{tabular}


When considered the intended purposes of the participants about sports fields in the parks, it is seen that $315(37 \%)$ of the participants chose living a healthy life and $46(5.4 \%)$ of the participants chose having a clear mind by doing sport. The results of the study done by Tatli (31) indicated that most of the participants (65.7\%) use sports parks for living a healthy life, while the results of the study done by Ay (4) indicated that most of the participants $(66.7 \%)$ coming to sport parks for ensuring the weight control.

Considering the reasons for prefering parks for doing sport, free charge is the predominant reason and consist of 261 persons (30.6\%), environment and hygiene problems of gyms are least effective reasons and consist of 38 persons $(4.5 \%) . \% 31.4$ of the participants chose the reason "for doing sport in fresh air" according to results of the study done by Ay (4).

It is seen that participants mostly prefered the "feeling healthy and spry" option after doing sport and consist of 271 person (31.8\%) and "feeling peaceful" is the least preferred option consist of 80 person (9.4\%). The study done by Ay (4) indicated that most of the participants (52.9\%) felt tired and exhausted after doing sport. As a result of the study done by Ağ1lönü (1) most of the reasons for doing sports are personality development $22 \%$, ensure the status, have fun and hold on to the life and also lose weight. According to Mengütay et al. (19), $10.7 \%$ of the participants' preferred "it contributes to health" option. "Health" factor is placed on the top when considering the factors motivating the participants in to recreational activities who getting service from Private Medical- Sport Centres as to study done by Güngörmüş (28).

The participantswant to working out under the supervision of sport specialists in the parks at high level, consist of 671 person $(78.8 \%)$.Considering the results it is seen that the study is similar to some other studies and also difference from some other studies. As a result of the study done by Tatl (31), most of the participants (91.6\%) agreed that sports activities must be carried out under the supervision of specialists. In the study done by Simsek et al. (28) and named as "A Study Relating to Open Field Exercise Parks and Users", most of the participants (81\%) want to work out under the supervision of sport specialists.
In the study done by Ay (4) and named as "Advantages and Disadvantages of Using Exercises Areas in the Parks Burdur City Center Study", similar results were obtained. All the age groups defended working out under the supervision of sport specialists.

Considering the relationship between gender and purposes of the participants, women's prior purposeis ensuring the weight control (78.7\%), while men's prior purpose of using sports implements in the parks is developing their muscles $80.3 \%$. When the study done by Ay (4) considered as to gender, the results indicated that $44.8 \%$ of the men and $75.3 \%$ of women responded as ensure the weight control. As a result of the study done by Tsai (13) with the participation of 246 men and 45 women, it was determined that exercise motivation levels of the participants dont differentiate at the sub-dimensions according to according togender of the individuals.

Considering the reasons of choosing parks for doing sport and educational status, primary and secondary school graduates (respectively, 46.6\%, $34.0 \%$ ) prefer parks because their children can play in the park while they are doing sport, high school graduates $36.8 \%$ prefer park because the gyms have environment and hygiene problems, university and above graduates $32.4 \%$ prefer parks beacuse gym membership fees are high. Gumus (3) have madethe studies ofindividuals who haveprimary leveleducation, secondary-school and university level, they participate more positive reasons than those individuals with education (3). Aşıkkutlu (27) concluded that the park vary according to the use of education. Searle \& Jackson (25) the level of educationin the work that has been done to the sport in the recreational park states that the restrictive reduced to increase sports.

\section{REFERENCES}

1. Agilonu A. Yerel Yonetimlerde Rekreasyon Hizmetleri ve Model Belirleme (Fethiye Ornegi). Marmara Universitesi Saglik Bilimleri Enstitusu, Doktora Tezi, İstanbul, 2007.

2. Alexandris K, Carroll B. Demographic Differences in the Perception of Constraints on Recreational Sport Participation: Result from a Study in Greece. Leisure Studies, 1997; (16): 107-125.

3. Asikkutlu HS. Rekreasyonel Motivasyon ve Kisitlayicilar; Ankara Goksu Parki ve Harikalar Diyari Parki Ornegi. Yuksek Lisans tezi, Duzce Universitesi, Duzce, 2008.

4. Ay O. Parklarda Bulunan Egzersiz Alanlarini Kullanmanin Yararlar ve Zararlari Burdur İl Merkezi Calismasi. Saglik Bilimleri Enstitusu, Yuksek Lisans Tezi, Burdur, 2012. 
5. Bilgic V. Degisik Yonleriyle Yerellesme, Ankara, Seckin Yayinlari, 2009.

6. Borrie WT. Measuring the Multiple, Deep and Unfolding Aspects of the Wilderness Experience Using the Experience Sampling Method, Faculty of the Virginia Polytechnic Institute and State University, Ph.D.Thesis, Blacksburg, Virginia,1995.

7. Bucher AC, Richard D. Recreation for Today's Society, Prentice-Hall, New Jersey, 1974.

8. Bulgu N, Aritan CK, Asci FH. Gundelik Yasam, Kadin ve Fiziksel Aktivite, Hacettepe Journal of Sport Sciences, 2007; 18 (4):167-18

9. Demir C. Milli Parklarda Turizm ve Rekreasyon Faaliyetlerinin Surdurulebilirligi: Turkiye'deki Milli Parklara Yonelik bir Uygulama, Doktora Tezi, Dokuz Eylul Universitesi, Sosyal Bilimler Enstitusu, 2001.

10. Dishman RK, Washburn RA, Heath GW. Physical Activity Epidemiology. Champaign İL; Human K1inetics, 2004.

11. Dogu G, Kesim U, Sivrikaya O. Belediyelerin Sporla ilgili islevleri: Duzce Belediyesi Ornegi, Cagdas Yerel Yonetimler Dergisi, 2002; 11(2 ):12-19.

12. Erdem İ. Yerel Siyaset ve Belediyecilik. İstanbul, İlke Yayinlari, 2011.

13. Gumus H. Fiziksel Aktivite İcin Park ve Rekreasyon Alanlarina Gelen Kullanicilarin Mekân Secimini ve Fiziksel Aktiviteye Katilimini Etkileyen Faktorler. Gazi Universitesi Saglik Bilimleri Enstitusu, Ankara, 2012.

14. Gungormus HA. Ozel Saglik-Spor Merkezlerinden Hizmet Alan Bireyleri Rekreasyonel Egzersizlere Guduleyen Faktorler. Doktora. Tezi, Gazi Universitesi, Saglik Bilimleri Enstitusu, Ankara, 2007.

15. Henderson KA. Theory application and development in recreation, park and leisure research. Journal of Park and Recreation Administration, 1994; 26: 421-425.

16. Karakucuk S. Bos Zamanlari Degerlendirme, Rekreasyon. 6 Baski, Ankara, Ozbaran ofset matbaacilik, 2008

17. Kilbas S. Genclik ve Bos Zamani Degerlendirme. Adana, Cukurova Universitesi Basimevi, 1994.

18. Lawlor DA, Hopker SW. The Effectiveness of exercise as an intervention in the management of depression: Systematic review and meta-regression analysis of randomized controlled trials. British Medical Journal, 2001; 322:1-8.

19. Mengutay S, Zorba E, Agilonu A, Cerit E, Agilonu O. Yerel yonetimlerde calisanlarin katildiklari rekreatif etkinliklere yonelten nedenler ve kazanimlari (Mugla Belediyesi ornegi). 9. Uluslararasi Spor Bilimleri Kongresi, 2006: 6(2);160-176.

20. Macnaghten P, Urry J. Bodies in the woods, Body and Society, 2000; 6 (3): 166 - 182.

21. Morgan WP. Physical activity, fitness, and depression. In Bouchard C, Shephard RJ, Stephens T, eds. Physical activity, fitness, and health. Champaign İL: Human Kinetics, 1994: 851-67.

22. North TC, Mc Cullagh P, Zung VT. Effect of Exercise on depression. Exercise and Sport Sciences Reviews, 1990; 18: 379-415.
23. Ozdemir AS, Karakucuk S, Gumus M, Kiran S. Turkiye Tas Komuru Kurumu Genel Mudurlugunde calisan yer alti iscilerinin bos zamanlarini degerlendirme aliskanliklarinin belirlenmesi. 9. Uluslararasi Spor Bilimleri Kongresi, Mugla, 2006.

24. Ozguc N. Turizm Cografyasi: Ozellikler Bolgeler, 2. Basim, İstanbul: Cantay Kitapevi, 1998.

25. Rodríguez L, Ortiz R. Implementing the balanced scorecard in public sector agencies: An experience in municipal sport services. Academia, Revista Latinoamericana de Administración, 2010; 45: 116-139.

26. Salihoglu BC. Artvin Hatila Vadisi Milli Parki dogal kaynak degerlerinin rekreasyonel niteliginin incelenmesi. Yuksek Lisans Tezi, Karadeniz Teknik Universitesi Fen Bilimleri Enstitusu, Trabzon, 1997.

27. Searle M, Jackson E. Socio-economic variation in perceived barriers to recreation participation among would-be participants. Leisure Sciences, 1985; 7: 227-249.

28. Simsek D, Katirci H, Akyildiz M, Sevil G. Acik Alan Egzersiz Parklari ve Kullanicilarina iliskin Bir Arastirma. Spor metre. Beden Egitimi ve Spor Bilimleri Dergisi, 2011; (9): 41-48

29. Sivrikaya O. Duzce Belediyesinin spor hizmetleri icin ornek bir yonetim modeli. Abant İzzet Baysal Universitesi Sosyal Bilimler Enstitusu, Yayimlanmamis Doktora Tezi, Düzce, 2009.

30. Sixt S, Beer S, Bluher M, Korff N, Peschel T. Long- but not short-term multifactorial intervention with focus on exercise training improves coronary endothelial dysfunction in diabetes mellitus type 2 and coronary artery disease. European Heart Journal, 2010; 31: 112-119.

31. Tatli CK. Yerel yonetimlerin yaptirdigi spor parklariyla ilgili sorunlar ve cozum onerileri (Mersin Ornegi). Yuksek Lisans Tezi, Egitim Bilimleri Enstitusu Beden ve Spor Anabilim Dali, Mersin, 2013.

32. Tezcan M. Sosyolojik Acidan Bos Zamanlarin Degerlendirilmesi, Ankara Universitesi Egitim Bilimleri Fakultesi Yayinlari, No: 116, Ankara, 1982.

33. Tsai EH. A Cross-cultural study of influence of perceived positive outcome on participation in regular active recreation: Hong Kong and Australian University. Leisure Sciences, 2005; 27(5): 385-404

34. Tucker P, Irwin JD, Gilliland J, Larsen K, Hess P. environmental influences on physical activity levels in youth. Health and Place, 2009; 15: 357-363. 